\title{
Nature in the Eye of the Beholder: A Case Study for Cultural Humility as a Strategy to Broaden Participation in STEM
}

\author{
Maria N. Miriti \\ Department of Evolution, Ecology and Organismal Biology, The Ohio State University, 318 W. 12th Avenue, \\ Columbus, OH 43210, USA; miriti.1@osu.edu
}

Received: 12 November 2019; Accepted: 6 December 2019; Published: 8 December 2019

\begin{abstract}
Science, technology, engineering, and math (STEM) disciplines suffer from chronically low participation of women and underrepresented minorities. Diversity enhancement initiatives frequently attempt to mitigate skill deficits such as math skills in an attempt to improve preparedness of these students. However, such interventions do not address cultural or social barriers that contribute to the isolation and marginalization that discourage continued participation in STEM. Science exists and is developed within social constructs.; because of this, cultural conflicts can occur pertaining to contrasting cultural belief systems between educators and students, or to socially-biased perspectives that are embedded in disciplinary values. These conflicts are implicated in the low recruitment and retention of underrepresented students in STEM. To address the relationship between culture and STEM diversity, I present a case study that examines the role of culturally-biased views of nature on the lack of diverse participation in ecology and environmental biology. I conclude by advocating the use of inclusive, culturally-sensitive teaching practices that can improve the climate for underrepresented students and increase diverse recruitment and retention in STEM.
\end{abstract}

Keywords: cultural competence; biocultural homogenization; Anglo-Eurocentrism

\section{Introduction}

Lack of broad participation may be one of the biggest challenges to achieving diversity in science, technology, engineering, and math (STEM) disciplines. Interventions that range from "pipeline" strategies such as the Summer Research Opportunities Program (SROP) sponsored by the Big 10 Alliance Universities, funded programs such as the National Science Foundation's Louis Stokes Alliance for Minority Participation (LSAMP) grants, to prioritization of research funding for proposals that include meaningful broader impact strategies, have been developed to incentivize diverse participation in STEM. Access to research opportunities such as these figure prominently in STEM diversity enhancement strategies, and there is evidence-based support that such activities attract diverse participants [1-4]. Nevertheless, retention of underrepresented students remains low for many STEM disciplines [5]. Research opportunities are valuable for recruiting underrepresented students, but they do not readily address cultural and social barriers that can contribute to the isolation and marginalization that reduce student retention in STEM academic programs [6,7].

Cultural barriers in STEM participation may be challenging to address because of the value of objectivity in these disciplines and research emphases on empirical, objective, and largely non-cultural topics. However, Vakil and Ayers [8] caution that STEM is not independent of socio-political biases-scientific values and knowledge production have frequently omitted the contributions and experiences of those outside the dominant culture. Consequently, cultural and social barriers are exacerbated with low diversity in certain academic disciplines or institutions $[7,9,10]$. Barriers persist, 
in part, because of challenges to accept counter-narratives (e.g., [11]) from underrepresented groups; this will be extensively examined in the case study that follows. Counter-narratives from underrepresented people depict lived experiences that challenge traditional paradigms established by the dominant culture. Therefore, these narratives can raise awareness of institutional practices that are socially- or culturally-biased and contribute to marginalization. Many underrepresented students in STEM negotiate their degrees never seeing themselves represented in their major departments [7,12], which contributes to social isolation. Taken together, a catch-22 dilemma for STEM diversity efforts can emerge-low diversity in STEM contributes to social and cultural barriers among STEM practitioners and educators, which in turn compromises retention of underrepresented students.

Since science exists within social constructs, cultural conflicts can refer to contrasting cultural belief systems between educators and students, or to socially-biased perspectives that are embedded in disciplinary values. The former may be general to STEM education, but the latter is more commonly discipline-specific. To nurture diverse participation, cultural competence [13] or humility on the part of educators, rather than "deficit" approaches, is a promising method to increase recruitment and retention of underrepresented students.

To exemplify how cultural biases can be embedded in disciplinary values with negative consequences toward broad participation in STEM, I examine a foundational concept, in ecology and environmental sciences (EE), which is the role of nature. Although I am combining these disciplines, as a practicing ecologist, I feel it is worth noting that these two disciplines are not as synonymous in practice as they might seem to non-practitioners [14]. Ecology is defined in most textbooks as the scientific study of interactions that determine the distribution of life [14]. In contrast, as Donald Strong, editor-in chief of the journal Ecology argues, " . . ecology is science and environmentalism sometimes is and sometimes isn' $t^{\prime \prime}$ [15]. Strong goes on to conclude that ecology requires environmentalism, but attitudes towards environmental advocacy are not unilateral among ecologists. Based on recent survey data, ecologists self-define as researchers of the natural world with social responsibility ranking as a very low priority $[16,17]$. In contrast, environmentalists advocate on behalf of the environment and society. This distinction is meaningful because it reflects differences in training and curricula. Many environmental studies or environmental sciences programs include policy or social science courses that are not required in ecology programs. Nevertheless, both disciplines share culturally laden concepts of the natural world. The overall objective is to demonstrate how social and cultural factors influence scientific practice and science education.

As with other STEM disciplines, recruitment and retention of underrepresented students is notably low in EE despite much investment in diversity enhancement initiatives [18,19]. Taylor [19] reports that while ethnic minorities (including Asians) represent $29 \%$ of the Science and Engineering workforce, representation in environmental organizations, broadly defined, is only $16 \%$. This lack of representation is concerning given that climate change and environmental justice issues disproportionately and negatively impact people of color and people with low socioeconomic status [20], namely, those who are underrepresented in EE disciplines.

By examining relevant ecological, social science, and education literature, I describe how cultured perspectives can become embedded in, and influence scientific and teaching practice in EE. Papers for review were selected using the Web of Science and search terms that captured the concepts of ecological education, environmental education, STEM education, STEM diversity, culture, cultural competence or humility and broadening participation. The rest of this paper will consist of four sections. In the first, I present cultural biases in the definition of nature, and how this definition influences disciplinary priorities. I will also present efforts within EE to address cultural biases in professional practice. In the following section, I present studies documenting how narrow biases stemming from cultured perceptions of nature negatively impact the recruitment of underrepresented students. Third, I present inclusive pedagogical strategies that have been advocated for both EE and STEM education that can improve cultural conflicts with the goal of broadening participation. I conclude with a discussion of how disciplinary attitudes towards the public can detract from achieving diversity and inclusion goals, 
and I present studies that support the use of inclusive, culturally sensitive teaching practices that can improve the climate for underrepresented students and increase their recruitment and retention.

The objective of this article is to exemplify how the social construction of science can reduce broad participation, and introduce culturally responsive teaching interventions that may improve recruitment and retention of underrepresented students. As will be presented below, the knowledge production that informs all science is the product of human interactions that are vulnerable to social and political influence. Therefore, this discipline-specific case study can serve as a template for interrogating and mitigating cultural biases in other academic disciplines that strive to broaden participation. The application of culturally competent education in other STEM disciplines will involve similar examination of the social and cultural influences on foundational, disciplinary values.

\section{Cultural Biases in the Concept of Nature}

"Our efforts to engender respect and inspire active participation in the care and management of our forests and parks means embracing the cultural experiences and environmental values of all segments of American society." ([21], p. 9)

The statement is a reminder that culture influences ways of knowing and learning that include perceptions of the natural world and the value of nature [21-23]. The prevailing paradigm of nature in an ecological sense, and one that informs the environmental movement, including conservation and the designation of National Parks, has been determined largely by white, middle- or upper-class, men such as John Muir, Henry David Thoreau, and John James Audubon [21,23-25]. This paradigm reflects their values and positions on nature as remote and pristine with little influence from human activity. It is noteworthy that the concept of pristine nature is debated within EE for reasons that include its disregard for pre-colonial human activity, even in regions as iconic as the Amazon (e.g., [26]), and the observation that in the current Anthropocene, human impacts are too pervasive to be ignored in any contemporary habitat (e.g., [27]). Nevertheless, these debates do not confront the cultural biases embedded in disciplinary priorities and values that stem from the accepted concept of nature.

Within the current decade, however, prominent ecologists have acknowledged that race, ethnicity, class, and gender are embedded in disciplinary values and practice (e.g., [28]). Unfortunately, consideration of the social and disciplinary impact of these issues is most commonly encased in frameworks that do not directly address the lack of diverse participation. For example, in 2011, the Cary Institute for Ecosystem Studies, a not-for-profit environmental research organization, hosted a conference entitled, "Linking Ecology and Ethics for a Changing World." During this conference, ecologists, social scientists, and philosophers gathered to address, in part, the ethical relationship between human values and environmental decision-making. Within the two edited volumes that resulted from this collaboration $[29,30]$, ecological responsibility towards social issues, and the impact of "Anglo-Eurocentrism" on ecological priorities are linked to "biocultural homogenization" [28,31], a process that disregards cultural diversity in a manner that can lead to social injustice. (Rozzi $(2012,2013)$ uses the term "Eurocentrism." Other authors in the anthologies resulting from the 2011 Cary Conference (Rozzi et al. 2013) emphasize Anglo-American or Anglo-European influences. For simplicity, I use the term "Anglo-Eurocentrism" in reference to the collective conclusions from these collaborations.) However, these injustices are situated in a global context that emphasizes developing countries, and locations where linguistic barriers may exist. Aspects of the culture of ecology that can negatively impact disenfranchised people are acknowledged, and a cultural shift is advocated that includes and improves the ethical responsibility of ecologists to society.

Domestically, the impacts of narrow, normative perspectives such as Anglo-Eurocentrism are considered in terms of gendered [32], or otherwise privileged concepts of nature that compromise environmental justice [28,33,34], ethical environmental education [35], and communication with non-scientists [36,37]. For example, Poole and colleagues [35] describe how divorcing societal dimensions from ecological education can compromise ethical management decisions on environmental problems. In these presentations, the responsibility of ecologists to societal issues is promoted; in other 
words, the domain of the discipline resides beyond an "ivory tower" and has social ramifications. These disciplinary examinations of the social and ethical consequences of scientific culture provide a valuable and much needed opportunity to adjust disciplinary priorities and practices. However, they do not address the impact of class, gender, and race on who participates in EE research and decision-making and who does not.

\section{Cultural Barriers in Ecology and Environmental Biology}

"... the development of knowledge is a necessarily social rather than individual activity, and it is the social character of scientific knowledge that both protects it from and renders it vulnerable to social and political interests and values.... science is socially constructed." ([38], p. 12)

Longino's assertion is not to argue that science is a social construct, but to position the practice of science within the realm of societal influences. Consideration of the problem of low disciplinary diversity generally does not question the role of Anglo-Eurocentrism itself as a barrier to recruitment of underrepresented students. More commonly, low representation is linked to issues that are correlated with underrepresented groups such as educational limitations (e.g., [39]) or unique responses to nature that are not conducive to disciplinary expectations (e.g., [40]). Not to diminish the importance of such factors, but they shift the cultural lens away from the disciplinary culture to that of broader society and various underrepresented groups. This shift can present cultural barriers in EE that can undermine the ability to attract and retain underrepresented students.

Recognizing that Anglo-Eurocentrism influences how EE practitioners interact with society at large allows the possibility that this narrow perspective influences recruitment and retention of underrepresented students. Bias in prevailing attitudes of what is nature or the value of experiences in nature, can present cultural confrontations in EE education if the experiences or perceptions of non-dominant populations are not included in disciplinary values.

Cultured definitions of the natural world are most readily exemplified when considering fieldwork. Fieldwork, or conducting research in natural settings, is identified as a transformative experience in the training of many who pursue EE degrees, and was recently endorsed by the Ecological Society of America as a relevant skill that should be included in ecology curricula [41]. It is perhaps not surprising that field experiences figure prominently in discussions of underrepresentation in EE.

A common perception is that minority and low-income populations do not value the environment, which in turn contributes to low representation of minority and low-income students in EE, in part because of a reluctance to participate in fieldwork. This perception of low environmental valuing represents a cultural confrontation because it is not supported by quantitative studies [42-44]. Pearson and colleagues [43] present this cultural mismatch as an "environmental belief paradox." Although this misperception may be associated with individuals conflating studies examining urban students' attitudes towards nature (e.g., [45]), it is consistent with the omission of diverse experiences in the prevailing concepts of nature $[21,23,46]$. In other words, if a person's concept of nature lies outside of the accepted definition, for example, a person who has never been to a national park or does not enjoy being in remote areas, they are not recognized as valuing nature. This cultural mismatch can contribute to low diversity in EE because of the relationship between social perceptions and individual performance.

Geiger and Swim [47] term inaccurate perceptions of the beliefs of others as pluralistic ignorance, and describe how social dynamics can lead to self-silencing of individuals based on fears of being perceived as lacking competence. Social cues influence performance in academic settings along with gender [48,49] and other underrepresented identities [50,51]. For example, studies of personal interactions between racially diverse or homogeneous groups of undergraduates suggest that racially homogeneous networks disadvantage minority, but not white, students [52]. These dynamics are related to self-efficacy and belonging. Self-efficacy, or a person's belief in their ability to succeed, is a strong predictor of academic performance among college students $[51,53,54]$, career choices among college-bound African American youth [55], and STEM performance among students globally [56]. 
Consequently, pervasive signals that students' understanding or experience is not included within disciplinary norms are not likely to encourage retention.

The role of pluralistic ignorance regarding valuing nature in EE education has not been directly examined, but it is implicated in studies suggesting that perceptions of discrimination [40] and the role of devalued racial experiences [57], that include racialized concepts of environmental valuing [58], serve as cultural barriers in EE education. These will be examined more thoroughly below.

\section{Cultural Humility and Education}

"No one has unmitigated experiences in/of the environment; rather all experiences in nature and conceptions of the environment are always culturally mediated." ([24], p.1)

The cultural dimensions of the definition of nature and perceptions of which demographics value nature exemplify distinct cultural lenses between educators and students that can contribute to poor retention of underrepresented students. The average ecologist is a 55-year-old, white male who values field work [59] and devalues social responsibility [16]. Therefore, most educators at the college level will be white and male, in contrast to a student population that is anticipated to be increasingly diverse. Sensitivity to cultural differences on the part of educators and mentors will be a necessary tool to increase positive experiences of nature for diverse students and to nurture a foundation that can increase diversity in EE professions.

Cultural competence, an approach first applied in medical disciplines [13], offers a promising framework to address barriers to broad recruitment and retention in STEM education. This framework is in contrast to common "pipeline" strategies that tend to employ interventions aimed to improve critical-thinking, communication skills (e.g., writing), or to provide research experiences. Recent studies in pedagogy and scientific communication challenge such "deficit" (sensu [60]) approaches by examining disciplinary and institutional practices that contribute to lower recruitment and retention of underrepresented students $[61,62]$. Research training is an important component of STEM education, but there is increasing recognition $[5,8,63,64]$ that awareness of social identities (i.e., cultural competency or humility), can support institutional and disciplinary efforts to diversify STEM participation at all educational levels.

Cultural humility in education promotes an "intercultural" awareness that responds to the biases that, intentionally or not, are part of academic disciplines. An "intercultural" pedagogy fosters inclusivity by appreciating that individual and collective identities influence learning [65]. Humility on the part of instructors and advisors is in recognition of the demographic skewedness that exists in higher education and that favors white, middle-, and upper-class people.

The pedagogical significance of culture is gaining traction in EE. A number of environmental education scholars promote the inclusion of environmental understanding and environmental contributions of non-dominant groups as part of the curriculum $[24,57,63,66,67]$. Jenkins [66] notes that because cultures are typically distributed discretely, curricula may consequently become more local than is customary in order to adapt to student-centered pedagogies. Such a strategy is similar to participatory approaches that have been applied in civic settings (e.g., [68-70]). Similarly, the interrelatedness of nature and culture in the context of fieldwork is beginning to be embraced by EE practitioners who accept that traditional ways of thought regarding nature are not inclusive [67]. The integration of culture in teaching can be viewed as analogous to the conventional awareness of the significance of local, natural history that is employed when conducting fieldwork.

In addition to a greater awareness of cultural contributions to disciplinary biases, culturally responsive pedagogy [71], or empathy on the part of educators, can increase the retention of underrepresented students. Instructors have little influence on the past experiences of their students, but instructors can practice sensitivity to their diverse ways of knowing. Active-learning practices have been adopted in many college courses in lieu of traditional lecture-based course designs. As a complement to active-learning, or student-centered pedagogies, Cotner and Balen [61] advocate alternative evaluation methods such as mixed assessments that reduce reliance on high-stakes exams to improve performance 
of women in STEM. Such practices involve competence training on the part of educators, and the development of novel curricula. Further, these interventions require broad institutional support in order to be sustainable. Nevertheless, they should be encouraged. STEM-specific models for inclusive teaching strategies that include cultural sensitivity are becoming more readily available for undergraduate education $[72,73]$ and promise to be adaptable to discipline-specific challenges.

Finally, it is important to consider cultural biases in the use of language in education. Metaphors are a commonly used tool to simplify complex information, but these can also be value-laden in favor of dominant cultural values that can exclude underrepresented students [74]. Language is a way of knowing, and as such, it can bias the accumulation of scientific information and how that information is communicated [28,75,76]. In his presentation of biocultural ethics, Rozzi [28] argues that one loss of cultural diversity in knowledge is due to the language limitations in accruing formal knowledge. Similarly, Kolawole [77] echoes the need for scientific institutions to create opportunities to be more inclusive in the way knowledge is produced. Although not every culture can be fairly represented in a single classroom, participatory, student-centered pedagogies provide a template for sharing broader experiences in an inclusive manner.

\section{Conclusions}

The value of STEM diversity is frequently presented in terms of the societal benefits that can be improved when individuals with different experiences collaborate to solve problems [78-80]. Within $\mathrm{EE}$, global issues such as climate change and environmental justice are most commonly discussed as disciplinary topics with societal consequences (e.g., $[3,66])$. However, the question of societal responsibility should not end with these justice issues. EE practitioners make decisions that affect the natural world. Independent of disciplinary definitions, these choices are felt broadly in terms of perceived abilities to participate in decision-making and in terms of the quality of local natural resources.

Culturally competency can influence teaching in other STEM disciplines, but the willingness to examine cultural biases that are embedded in individual scientific disciplines is required. Geosciences [81] and anthropology [82] are currently confronting the societal and cultural biases embedded in their respective disciplinary practices, including the recognition that these influence a lack of diverse participation. There are even science educators that are willing to address such polemic issues as the perspective that religion and science cannot coexist by asserting the separation of belief systems and scientific practice [83]. Science is not something to be believed in, it strives to produce knowledge using empirical practices that can be reproduced. To increase STEM diversity, confronting the ways in which science exists and is developed in a social context can help increase diversity. This confrontation can stimulate development of culturally-sensitive strategies to recruit and retain the talent of those with diverse, underrepresented experiences.

Funding: This research received no external funding.

Conflicts of Interest: The author declares no conflict of interest.

\section{References}

1. Markowitz, D.G. Evaluation of the Long-Term Impact of a University High School Summer Science Program on Students' Interest and Perceived Abilities in Science. J. Sci. Educ. Technol. 2004, 13, 395-407. [CrossRef]

2. Packard, B.W.L.; Nguyen, D. Science career-related possible selves of adolescent girls: A longitudinal study. J. Career Dev. 2003, 29, 251-263. [CrossRef]

3. Armstrong, M.J.; Berkowitz, A.R.; Dyer, L.A.; Taylor, J. Understanding why underrepresented students pursue ecology careers: A preliminary case study. Front. Ecol. Environ. 2007, 5, 415-420. [CrossRef]

4. Flowers, S.K.; Beyer, K.M.; Visions, E.; Avenue, A.; Louis, S. Early entry into ecology: Authentic field research experiences for high school youth. Bull. Ecol. Soc. Am. 2016, 97, 111-122. [CrossRef]

5. Allen-Ramdial, S.A.A.; Campbell, A.G. Reimagining the pipeline: Advancing STEM diversity, persistence, and success. Bioscience 2014, 64, 612-618. [CrossRef] 
6. Foor, C.E.; Walden, S.E.; Trytten, D.A. "I wish that I belonged more in this whole engineering group": Achieving individual diversity. J. Eng. Educ. 2007, 96, 103-115. [CrossRef]

7. McGee, E.O. Devalued Black and Latino Racial Identities. Am. Educ. Res. J. 2016, 53, 1626-1662. [CrossRef]

8. Vakil, S.; Ayers, R. The racial politics of STEM education in the USA: Interrogations and explorations. Race Ethn. Educ. 2019, 22, 449-458. [CrossRef]

9. Mascarenhas, M. White Space and Dark Matter: Prying Open the Black Box of STS. Sci. Technol. Hum. Values 2018, 43, 151-170. [CrossRef]

10. Espinosa, L.L. Pipelines and Pathways: Women of Color in Undergraduate STEM Majors and the College Experiences That Contribute to Persistence. Harv. Educ. Rev. 2011, 81, 209-240. [CrossRef]

11. Solórzano, D.G.; Yosso, T.J. Critical race methodology: Counter-storytelling as an analytical framework for education research. Qual. Inq. 2002, 8, 23-44. [CrossRef]

12. Puritty, C.; Strickland, L.R.; Alia, E.; Blonder, B.; Klein, E.; Kohl, M.T.; McGee, E.; Quintana, M.; Ridley, R.E.; Tellman, B.; et al. Without inclusion, diversity initiatives may not be enough. Science 2017, 357, 1101-1102. [CrossRef] [PubMed]

13. Smith, L.S. Concept analysis: Cultural competence. J. Cult. Divers. 1998, 5, 4-10. [PubMed]

14. Westoby, M. What does "ecology" mean? Trends Ecol. Evol. 1997, 12, 166. [CrossRef]

15. Strong, D.R. Ecologists and environmentalism. Front. Ecol. Environ. 2008, 6, 347. [CrossRef]

16. Reiners, W.A.; Reiners, D.S.; Lockwood, J.A. Traits of a good ecologist: What do ecologists think? Ecosphere 2013, 4. [CrossRef]

17. Reiners, D.S.; Reiners, W.A.; Lockwood, J.A. The relationship between environmental advocacy, values, and science: A survey of ecological scientists' attitudes. Ecol. Appl. 2013, 23, 1226-1242. [CrossRef]

18. Beck, C.; Boersma, K.; Tysor, C.S.; Middendorf, G. Diversity at 100: Women and underrepresented minorities in the ESA: Peer-reviewed letter. Front. Ecol. Environ. 2014, 12, 434-436. [CrossRef]

19. Taylor, D.E. The State of Diversity in Environmental Organizations; University of Michigan: Ann Arbor, MI, USA, 2014.

20. Schwarz, K.; Fragkias, M.; Boone, C.G.; Zhou, W.; McHale, M.; Grove, J.M.; O’Neil-Dunne, J.; McFadden, J.P.; Buckley, G.L.; Childers, D.; et al. Trees grow on money: Urban tree canopy cover and environmental justice. PLoS ONE 2015, 10, e0122051. [CrossRef]

21. Finney, C. Black Faces, White Spaces: Reimagining the Relationship of African Americans to the Great Outdoors; The University of North Carolina Press: Chapel Hill, NC, USA, 2014.

22. Callicott, J.B. The worldview concept and Aldo Leopold's project of "world view" remediation. In Linking Ecology and Ethics for a Changing World: Values, Philosophy, and Action; Rozzi, R., Palmer, C., Callicott, J.B., Pickett, S.T.A., Armesto, J.J., Eds.; Springer Science \& Business Media: Dordrecht, The Netherlands, 2013; pp. 113-124.

23. Taylor, D.E. American environmentalism: The role of race, class and gender in shaping activism 1820-1995. Race Gend. Cl. 1997, 5, 16-62.

24. Stapleton, S.R. Toward critical environmental education: A standpoint analysis of race in the American environmental context. Environ. Educ. Res. 2019, 4622,1-16. [CrossRef]

25. Taylor, D.E. Race, Class, Gender, and American Environmentalism; General Technical Report; Department of Agriculture, Forest Service, Pacific Northwest Research Station: Portland, OR, USA, 2002.

26. Clement, C.R.; Denevan, W.M.; Heckenberger, M.J.; Junqueira, A.B.; Neves, E.G.; Teixeira, W.G.; Woods, W.I. The domestication of amazonia before european conquest. Proc. R. Soc. B Biol. Sci. 2015, 282. [CrossRef] [PubMed]

27. Kareiva, P.; Marvier, M. What is conservation science? Bioscience 2012, 62, 962-969. [CrossRef]

28. Rozzi, R. Biocultural ethics: Recovering the vital links between the inhabitants, their habits, and habitats. Environ. Ethics 2012, 34, 27-50. [CrossRef]

29. Rozzi, R.; Pickett, S.T.A.; Palmer, C.; Armesto, J.J.; Callicott, J.B. (Eds.) Linking Ecology and Ethics for a Changing World: Values, Philosophy, and Action; Springer Science \& Business Media: Dordrecht, The Netherlands, 2013.

30. Rozzi, R.; Chapin, F.S., III.; Callicott, J.B.; Pickett, S.T.A.; Power, M.E.; Armesto, J.J.; May, R.H., Jr. (Eds.) Earth Stewardship: Linking Ecology and Ethics in Theory and Practice; Springer International Publishing: Cham, Switzerland, 2015. 
31. Rozzi, R. Biocultural ethics: From biocultural homogenization toward biocultural conservation. In Linking Ecology and Ethics for a Changing World: Values, Philosophy, and Action; Rozzi, R., Pickett, S.T.A., Palmer, C., Armesto, J.J., Callicott, J.B., Eds.; Springer Science \& Business Media: Dordrecht, The Netherlands, 2013; pp. 9-32.

32. Mallory, C. Environmental justice, ecofeminism, and power. In Linking Ecology and Ethics for a Changing World: Values, Philosophy, and Action; Rozzi, R., Pickett, S.T.A., Palmer, C., Armesto, J.J., Callicott, J.B., Eds.; Springer Science \& Business Media: Dordrecht, The Netherlands, 2013; pp. 251-258.

33. Kingsland, S.E. Ecological science and practice: Dialogues across cultures and disciplines. In Earth Stewardship: Linking Ecology and Ethics in Theory and Practice; Rozzi, R., Chapin, F.S., III., Callicott, J.B., Pickett, S.T.A., Power, M.E., Armesto, J.J., May, R.H., Jr., Eds.; Springer International Publishing: Cham, Switzerland, 2015; pp. 17-26.

34. Uriarte, M.; Ewing, H.A.; Eviner, V.T.; Weathers, K.C. Constructing a Broader and More Inclusive Value System in Science. Bioscience 2007, 57, 71-78. [CrossRef]

35. Poole, A.K.; Hargrove, E.C.; Day, P.; Forbes, W.; Berkowitz, A.R.; Feinsinger, P.; Rozzi, R. A call for ethics in environmental education. In Linking Ecology and Ethics for a Changing World: Values, Philosophy, and Action; Rozzi, R., Pickett, S.T.A., Palmer, C., Armesto, J.J., Callicott, J.B., Eds.; Springer Science \& Business Media: Dordrecht, The Netherlands, 2013; pp. 349-360.

36. Nadkarni, N.M. Not such strange bedfellows: Underserved public audiences as collaborators for ecologists. In Linking Ecology and Ethics for a Changing World: Values, Philosophy, and Action; Rozzi, R., Pickett, S.T.A., Palmer, C., Armesto, J.J., Callicott, J.B., Eds.; Springer Science \& Business Media: Dordrecht, The Netherlands, 2013; pp. 333-348.

37. Nadkarni, N.M.; Weber, C.Q.; Goldman, S.V.; Schatz, D.L.; Allen, S.; Menlove, R. Beyond the deficit model: The ambassador approach to public engagement. Bioscience 2019, 69, 305-313. [CrossRef]

38. Longino, H.E. Science as Social Knowledge; Princeton University Press: Princeton, NJ, USA, 1990.

39. Gutman, L.M.; Sameroff, A.J.; Eccles, J.S. The academic achievement of African American students during adolescense: An examination of multiple risk, promotive, and protective factors. Am. J. Community Psychol. 2002, 30, 367-400. [CrossRef]

40. Haynes, N.A.; Jacobson, S. Barriers and Perceptions of Natural Resource Careers by Minority Students. J. Environ. Educ. 2015, 46, 166-182. [CrossRef]

41. Klemow, K.; Berkowitz, A.; Cid, C.; Middendorf, G. Improving ecological education through a four-dimensional framework. Front. Ecol. Environ. 2019, 17, 71. [CrossRef]

42. Taylor, D.E. Racial and ethnic differences in connectedness to nature and landscape preferences among college students. Environ. Justice 2018, 11, 118-136. [CrossRef]

43. Pearson, A.R.; Schuldt, J.P.; Romero-Canyas, R.; Ballew, M.T.; Larson-Konar, D. Diverse segments of the US public underestimate the environmental concerns of minority and low-income Americans. Proc. Natl. Acad. Sci. USA 2018, 115, 12429-12434. [CrossRef] [PubMed]

44. Mohai, P. Dispelling old myths: African American concern for the environment. Environ. Sci. Policy Sustain. Dev. 2003, 45, 10-26. [CrossRef]

45. Bixler, R.D.; Carlisle, C.L.; Hammitt, W.E.; Floyd, M.F. Observed fears and discomforts among urban students on field trips to wildland areas. J. Environ. Educ. 1994, 26, 24-33. [CrossRef]

46. Mizelle, R.M. Race and environmental history. Hist. Compass 2019, 17, e12527. [CrossRef]

47. Geiger, N.; Swim, J.K. Climate of silence: Pluralistic ignorance as a barrier to climate change discussion. J. Environ. Psychol. 2016, 47, 79-90. [CrossRef]

48. Cheryan, S.; Ziegler, S.A.; Montoya, A.K.; Jiang, L. Why Are Some STEM Fields More Gender Balanced Than Others? Psychol. Bull. 2017, 143, 1-35. [CrossRef]

49. Cheryan, S.; Plaut, V.C.; Davies, P.G.; Steele, C.M. Ambient Belonging: How Stereotypical Cues Impact Gender Participation in Computer Science. J. Personal. Soc. Psychol. 2009, 97, 1045-1060. [CrossRef]

50. Steele, C.M.; Spencer, S.J.; Aronson, J. Contending with group image: The psychology of stereotype and social identity threat. Adv. Exp. Soc. Psychol. 2002, 34, 379-440.

51. Walton, G.M.; Cohen, G.L. A brief social-belonging intervention improves academic and health outcomes of minority students. Science 2011, 331, 1447-1451. [CrossRef] 
52. Wout, D.A.; Murphy, M.C.; Steele, C.M. When your friends matter: The effect of White students' racial friendship networks on meta-perceptions and perceived identity contingencies. J. Exp. Soc. Psychol. 2010, 46, 1035-1041. [CrossRef]

53. Freeman, T.M.; Anderman, L.H.; Jensen, J.M. Sense of belonging in college freshmen at the classroom and campus levels. J. Exp. Educ. 2007, 75, 203-220. [CrossRef]

54. Walton, G.M.; Cohen, G.L. A question of belonging: Race, social fit, and achievement. J. Personal. Soc. Psychol. 2007, 92, 82-96. [CrossRef] [PubMed]

55. Quimby, J.L.; Wolfson, J.L.; Seyala, N.D. Social cognitive predictors of African American adolescents' career interests. J. Career Dev. 2007, 33, 376-394. [CrossRef]

56. Sanchez, C.; Dunning, D. Cultural Patterns Explain the Worldwide Perception/Performance Paradox in Student Self-Assessments of Math and Science Skill. Soc. Psychol. Personal. Sci. 2018, 10, 935-945. [CrossRef]

57. Nxumalo, F.; Ross, K.M. Envisioning Black space in environmental education for young children. Race Ethn. Educ. 2019, 22, 502-524. [CrossRef]

58. Quimby, J.L.; Seyala, N.D.; Wolfson, J.L. Social cognitive predictors of interest in environmental science: Recommendations for environmental educators. J. Environ. Educ. 2007, 38, 43-52. [CrossRef]

59. Lockwood, J.A.; Reiners, D.S.; Reiners, W.A. The future of ecology: A collision of expectations and desires? Front. Ecol. Environ. 2013, 11, 188-193. [CrossRef]

60. Miller, J.D. Scientific Literacy: A Conceptual and Empirical Review. Daedalus 1983, 112, $29-48$.

61. Cotner, S.; Ballen, C.J. Can mixed assessment methods make biology classes more equitable? PLoS ONE 2017, 12, e0189610. [CrossRef]

62. Estrada, M.; Burnett, M.; Campbell, A.G.; Campbell, P.B.; Denetclaw, W.F.; Gutiérrez, C.G.; Hurtado, S.; John, G.H.; Matsui, J.; McGee, R.; et al. Improving underrepresented minority student persistence in STEM. CBE Life Sci. Educ. 2016, 15. [CrossRef]

63. Quigley, D. Building Cultural Competence in Environmental Studies and Natural Resource Sciences. Soc. Nat. Resour. 2016, 29, 725-737. [CrossRef]

64. Gazley, J.L.; Remich, R.; Naffziger-Hirsch, M.E.; Keller, J.; Campbell, P.B.; McGee, R. Beyond preparation: Identity, cultural capital, and readiness for graduate school in the biomedical sciences. J. Res. Sci. Teach. 2014, 51, 1021-1048. [CrossRef] [PubMed]

65. Lee, A.; Poch, R.; O’Brien, M.K.; Solheim, C. Teaching Interculturally; Stylus Publishing, LLC.: Sterling, VA, USA, 2017.

66. Jenkins, E.W. Environmental education and the public understanding of science. Front. Ecol. Environ. 2003, 1, 437-443. [CrossRef]

67. Fleischner, T.L.; Espinoza, R.E.; Gerrish, G.A.; Greene, H.W.; Kimmerer, R.W.; Lacey, E.A.; Pace, S.; Parrish, J.K.; Swain, H.M.; Trombulak, S.C.; et al. Teaching Biology in the Field: Importance, Challenges, and Solutions. Bioscience 2017, 67, 558-567. [CrossRef]

68. Roth, W.M.; Lee, S. Science Education as/for Participation in the Community. Sci. Educ. 2004, 88, $263-291$. [CrossRef]

69. Schusler, T.M.; Krasny, M.E.; Decker, D.J. The autonomy-authority duality of shared decision-making in youth environmental action. Environ. Educ. Res. 2017, 23, 533-552. [CrossRef]

70. Krasny, M.E.; Russ, A.; Tidball, K.G.; Elmqvist, T. Civic ecology practices: Participatory approaches to generating and measuring ecosystem services in cities. Ecosyst. Serv. 2014, 7, 177-186. [CrossRef]

71. Warren, C.A. Empathy, Teacher Dispositions, and Preparation for Culturally Responsive Pedagogy. J. Teach. Educ. 2018, 69, 169-183. [CrossRef]

72. Dewsbury, B.M. On faculty development of STEM inclusive teaching practices. FEMS Microbiol. Lett. 2017, 364, 1-6. [CrossRef]

73. Dewsbury, B.; Brame, C.J. Inclusive Teaching. CBE Life Sci. Educ. 2019, 18, fe2. [CrossRef]

74. Taylor, C.; Dewsbury, B.M. On the Problem and Promise of Metaphor Use in Science and Science Communication. J. Microbiol. Biol. Educ. 2018, 19. [CrossRef] [PubMed]

75. Morrison, A.; Polisena, J.; Husereau, D.; Moulton, K.; Clark, M.; Fiander, M.; Mierzwinski-Urban, M.; Clifford, T.; Hutton, B.; Rabb, D. The effect of english-language restriction on systematic review-based meta-analyses: A systematic review of empirical studies. Int. J. Technol. Assess. Health Care 2012, 28, $138-144$. [CrossRef] [PubMed]

76. Franklin, S. Science asa culture, cultures of science. Annu. Rev. Anthropol. 1995, 24, 163-184. [CrossRef] 
77. Kolawole, O.D. Science, Social Scientisation and Hybridisation of Knowledges. Sci. Cult. 2019, 28, 391-401. [CrossRef]

78. Powell, K. The power of diversity. Nature 2018, 558, 19-22. [CrossRef] [PubMed]

79. Guterl, F. The inclusion equation. Sci. Am. 2014, 311, 38-40. [CrossRef]

80. Rothkopf, D. Science benefits from diversity. Nature 2018, 558, 5.

81. Winders, J.; Schein, R. Race and Diversity: What Have We Learned? Prof. Geogr. 2014, 66, 221-229. [CrossRef]

82. Antón, S.C.; Malhi, R.S.; Fuentes, A. Race and diversity in U.S. Biological Anthropology: A decade of AAPA initiatives. Am. J. Phys. Anthropol. 2018, 165, 158-180. [CrossRef]

83. Taber, K.S. Beliefs and Science Education. In Science Education; Taber, K.S., Akpan, B., Eds.; Sense Publishers: Rotterdam, The Netherlands, 2017; pp. 53-67.

C 2019 by the author. Licensee MDPI, Basel, Switzerland. This article is an open access article distributed under the terms and conditions of the Creative Commons Attribution (CC BY) license (http://creativecommons.org/licenses/by/4.0/). 